\title{
THE STRATEGIC ASPECTS AND RESULTS OF AGRICULTURE DEVELOPMENT IN SERBIA IN THE TRANSITION PERIOD
}

\author{
Jugoslav Aničić ${ }^{1}$, Svetlana Vukotić2 ${ }^{2}$ Svetozar Krstić ${ }^{3}$
}

\begin{abstract}
Summary
The economic development in Yugoslavia (Serbia) after the second world war has been conducted at the expense of agriculture because the industrialisation was in the forefront of the economic policy. It has an impact on the present position of the agriculture compared to the other sectors because the parity of product exchange is still retained at the expense of agriculture. Even under these circumstances agriculture is an industry with a positive foreign trade balance, important share in the national product and the unemployment rate reduction, and that has been analysed and shown in this paper. Many developed European countries are an example of the successful agricultural development as a carrier of the complete development. There are indisputably much wider possibilities for agriculture development in Serbia, and it could become a great comparative advantage of our economy in the developed markets in the world, with the appropriate macroeconomic policy.
\end{abstract}

Key words: agriculture, development, economic policy, business results, company

JEL: $Q 18, Q 13$

\section{Introduction}

The importance of agriculture as an industry is indisputable in every period, transition period included. When it comes to Serbia, we are the witnesses of the constant stress on the importance of agricultural production, reflected in various syntagma ranging from the lever of the complete economic development to one of the pillars marking the possibility for the progress of the whole country. All these things are especially intensified by the challenge to see agriculture as a competitive advantage that Serbia could make use of because of favourable natural conditions.

1 Jugoslav Aničić Ph.D., Associate Professor, Union Nikola Tesla University, Cara Dušana Street no. 62-64, Belgrade, Republic of Serbia, Phone: +381 1132869 61, E-mail: ajugoslav@yahoo.com

2 Svetlana Vukotić Ph.D., Associate Professor, Union Nikola Tesla University, Cara Dušana Street no. 62-64, Belgrade, Republic of Serbia, Phone: +381 1134281 42, E-mail: cecavukotic@gmail.com

3 Svetozar Krstić, M.A., Chamber of Commerce and Industry of Belgrade, Knez Miloša Street no. 12, 11000 Belgrade, Serbia, E-mail: krstics@kombeg.org.rs

EP 2016 (63) 1 (175-187) 
According to Pejanović and associates (2006), the transition in agriculture means a process of transition from the (previous) present model of (agriculture) economy to a new market economy concept, modelled upon the developed countries of the European Union. This transitional period took place in two phases during the first decade of the 21st century: the first one marked by privatisation and restructuring, and the other one by creating a stimulative macroeconomic environment, especially in the investment area. Disturbing factors in reaching these objectives were unavoidable, caused by the 2008 global financial crisis overflow. One of the positive shifts was in 2012, after half a century, when a list of agricultural holdings and their structure was made.

At the time of the beginning of the European integration process, the imperative imposed is approaching the European model of economy. Therefore, the Strategy of Agriculture and rural development of the Republic of Serbia for the 2014-2024 period defines three most important reform segments: 1. Agricultural policy reform; 2. Legislation adoption and complete application; 3. Institutional reforms. It is important to mention the importance of implementation for the segments proposed and defined.

From all the above mentioned arises the need to analyse, compare and show the achieved results of agriculture development, and they are the topic of this paper. The paper is conceived in three key parts. The first one defines the role and importance of agricultural production as an industry. The next is about macroeconomic indicators, the relations of agricultural production with other industries and structures. The final part is about business results of the companies in agriculture.

The objective of this paper is to indicate the need for policy, programme and initiative improvement in the function of the agriculture production opportunity increase in Serbia, to highlight agrarian role and importance, to suggest the future activities with an appreciation of experiences and good practice examples from the developed European countries. Thus, this paper can be of use to the expert public interested in these issues.

\section{The importance and the role of agricultural production}

Agriculture represents a very important industry in every country. Agriculture is an industry which uses the land and grows useful plants and animals for obtaining the primary products of plant and animal origin, then processes them within agricultural organisations and holdings in order to meet personal and social needs. Along with forestry, hunting and fishing, agriculture makes up the primary sector of the economy.

Agricultural products are a result of the previous human work which influences life functions of plants and animals, and uses them in a manner suitable for men. Its development defines the conditions for population nutrition, rural areas employment, and it is the most important factor in manufacturing industry, tourism and trade. It also represents a very important source of raw materials and demand for many industrial products.

According to Stefanović and Broćić (2012), there are some tendencies at the global level, encouraging harmonious development and increasing food production, as well as fast, 
rational and organised distribution of agricultural and food products in all parts of the world. The economic theory explains that a larger share of agricultural and food exports in the total exports of a country points to its lower level of economic development as a rule. However, there are some developed world countries where the export of these products can be a very important item in the foreign trade balance (Holland, Denmark, France, Canada, Australia).

According to Arzeni and associates (2016), agriculture will hardly reach a higher level of productivity and market success unless the complete rural industry can overcome some depression factors. The first important factor is a low level of income, decreasing local demand and investments, so there is no capital for funding of new companies or investments. The next one is the migration of young people into urban areas which causes a significant population aging. Therefore, the average level of education and improvement is decreasing. Finally, the physical infrastructure is generally poor, unsuitable and outdated, which unables easier access to markets and urban areas connections. Some of these problems are also present in the rural areas of the western Europe. However, in the transition countries, these appear all together, and cause even larger gap behind the urban areas.

Byerlee and associates (2009) point out that a new paradigm should recognise multiple functions of agriculture and its influence on the complete development. In this context, there are: economic growth, poverty decrease, lower income differences, food provision and environmental protection services. Yet, these functions of agriculture have been neglected, which resulted in its lower growth. These authors point out that $75 \%$ of the world population comes from the rural areas.

The importance of agriculture in the European Union can be observed through a few data which illustrate its part in the community's economy. Agriculture and food industry provide over 15 million workplaces in the European Union, that is $8.3 \%$ of all employed citizens of the Union. That is an average for the whole Union, and it differs considerably from country to country. In the so-called, ,old” members of the EU (15 industrialised, developed western European countries) there is an average of 4\%, whereas in the „new” EU members (Romania, Bulgaria, Slovakia, Hungary) there are more than $12 \%$ of the complete workforce in agriculture and the food industry (VapaTankosić, Stojsavljević, 2014).

The production of agriculture's share in the European countries' GDP is $2-3 \%$, but in the countries such as Bulgaria or Romania can be up to $10 \%$ of GDP. The total production value of agriculture in 2008 is estimated at 635 billion euros (European commission, 2012).

The falling share of agriculture in the national employment and GDP is the inevitable result of the economic progress. This is mainly due to higher elasticity in the demand for nonagricultural goods and services income. With their income growth, consumers increase produced goods and services expenditure faster than the food consumption. It is a paradox, but the process is usually followed by income growth and less common poverty among those depending on agriculture for a living (Cervates-Godoy, Dewbre, 2010).

On the other hand, according to Gulan (2016), it is expected of agriculture to bring economic 
development, enlarge GDP and serve as a framework of the complete economic stability. This is due to the fact that it is a real economic sector, which directly brings close to 15 percent of domestic product, indirectly even up to 40 percent, and its share in the export of the country is 23 percent. Therefore, agriculture should not stand for the poverty, but the wealth of the country. This is the reason to encourage agricultural development in order to valorise natural, human and manufacturing capacities to the maximum, since they are only used with one-third of the possibilities.

Also, the full usage of the agricultural potential is only possible if the small agricultural producers connect to the markets in the way which enables them to reach higher income and other benefits (Zakić et al., 2014).

According to industries, the highest real growth achieved in 2013 is in agriculture (20.9\%), followed by electricity supply sector $(13.0 \%)$, then transport and storage sector $(7.6 \%)$, and finally manufacturing industry $(5.7 \%)$. The rest of the industry showed no growth (Statistical Office of the Republic of Serbia, Statistical Yearbook, 2015).

However, from the realised investment aspect, the most investments went to basic funds in the manufacturing industry sector $(30.2 \%)$, construction and agriculture had the same share in the total investments-4.6\% each (Statistical Office of the Republic of Serbia, Statistical Yearbook, 2015).

Regardless of all the problems agriculture brings along, it is recognised as a chance for the development, and it is also considered as the backbone of progress when Serbia is concerned. According to the share of agriculture in wealth creation, Serbia is considered as one of the most agricultural countries in Europe, with the competition, which consists of Albania, Moldavia, and Bosnia and Herzegovina (Anufrijev, Dašić, 2012).

\section{Agricultural policy in the transition period in Serbia}

The present situation in Serbian agriculture has been considerably influenced by the condition inherited from the post-war period as well as the agricultural policy conducted in this period. As for the inherited condition, a specific fact is also the existence and development of the private as well as the public sector. The agricultural policy was directed toward public sector development, such as agricultural cooperatives and large conglomerates. These agricultural forms had larger investments, better technical equipment, more favourable workforce qualification structure, and higher work productivity as a result.

Compared to other areas of the economic system, it can be concluded that agriculture was neglected in the complete post-war period. The economic indicator of these relations is price disparities at the expense of agriculture, and they have still persisted until today. The slowdown in agriculture in the 1970s was particularly noticeable, and its lag behind the industry and other areas of the economy. Besides, there was a breakdown in the unique economic area of Yugoslavia in the 1990s, which caused even further decrease of production, closing within its own limits and general reproduction capabilities limitations. 
Among the most important causes of slower agriculture growth, we can single out the following (Devetaković et al., 2009):

- Permanent unfavourable economic conditions

- Formulation and implementation of the development concept inconsistency

- Long-term applied restrictions, mainly to the private property

- Agriculture negligence, especially private sector, in the economic policy

- Lack of consistent land policy

- Slow inclusion in irrigation and land reclamation.

Company and cooperative privatisation process in agriculture was not accompanied by the appropriate procedures which led to further decline of large conglomerates as the production carriers in pre-transition period. The situation is the same with cooperatives, where the law procedures were behind the rest of the social development process.

Small and medium-sized enterprises in agribusiness should be based upon considerable investments through various forms of credits. Farmers and SMEs in agriculture have the poorest access to finances among all sectors in Serbia, which offers a poor scope of credit resources in the area of agriculture. The existing mechanisms for agriculture financing are inadequate in Serbia so the changes are necessary in the approach itself. It can be achieved with the institutional support and equity from the banks, loan associations and leasing companies. Under the circumstances, SMEs development in agribusiness should be made through smallholding development (Bogavac-Cvetković et al., 2010). Farmers and SMEs in agriculture have the poorest access to finances among all sectors in Serbia, which offers a poor scope of credit resources in the area of agriculture. The existing mechanisms for agriculture financing are inadequate in Serbia so the changes are necessary in the approach itself.

Successful companies were the first to go into privatisation, often with the monopoly creation as in the dairy industry, where more than $60 \%$ of the domestic dairies is controlled by ,Salford” investment fund. In the course of the spearhead a lot of successful companies were sold-sugar refineries, breweries, water plants. Nobody took care about what should be sold, and recapitalisation as one of the best solutions for agricultural economics agronomics completely failed. The privatisation objective should be development and agricultural economics, efficiency increase, and the profit from this sector privatisation should be directed into agronomic development projects. Of course, a large number of people lost their jobs in agriculture as well as in other industries.

The share of agriculture in total GDP has been decreasing from the start of the transition period, which is the result of faster increase in non-production sectors, mainly trade. The agriculture share in the GVA structure in Serbian economics is still very high compared to the EU countries average. It could be explained as a result of rich natural resources and favourable climate factors on one hand, or as a result of a slower economic reform process in other sectors on the other hand. In table 1, we can see that the share of agriculture in the 
total employment is very high, over $20 \%$, and that is partly attributed to a large number of seasonal and temporary jobs. The share of agriculture in the foreign trade balance is very important for Serbia, the exports ca. $23 \%$, and the imports about $8 \%$, with a high coverage of imports by exports.

Table 1. Macroeconomic indicators of agriculture's contribution to the national economy of Serbia in 2010-2013 period

\begin{tabular}{|l|r|r|r|r|}
\hline Description & $\mathbf{2 0 1 0}$ & $\mathbf{2 0 1 1}$ & $\mathbf{2 0 1 2}$ & $\mathbf{2 0 1 3}$ \\
\hline Agriculture GVA share in the total GVA \% & 9.9 & 10.5 & 9.7 & 11.4 \\
\hline The share in the total employment (\%) & 22.2 & 21.2 & 21.0 & 21.3 \\
\hline The share in the total export of goods (\%) & 23.0 & 23.2 & 24.1 & 23.4 \\
\hline The share in the total import of goods (\%) & 6.6 & 7.4 & 8.3 & 8.2 \\
\hline Coverage of imports by exports (\%) & 207.6 & 185.8 & 174.5 & 178.8 \\
\hline
\end{tabular}

Source: The strategy of agriculture and rural development of the Republic of Serbia 2014-2024

Un-competitiveness is one of the main factors influencing the crisis in the agriculture sector. Thus, export capacities should be intensified because there is evidently agriculture product underestimation and that could represent not only the chance for export, but also a comparative advantage in foreign markets.

Pie chart 1. The structure of agriculture export in 2014

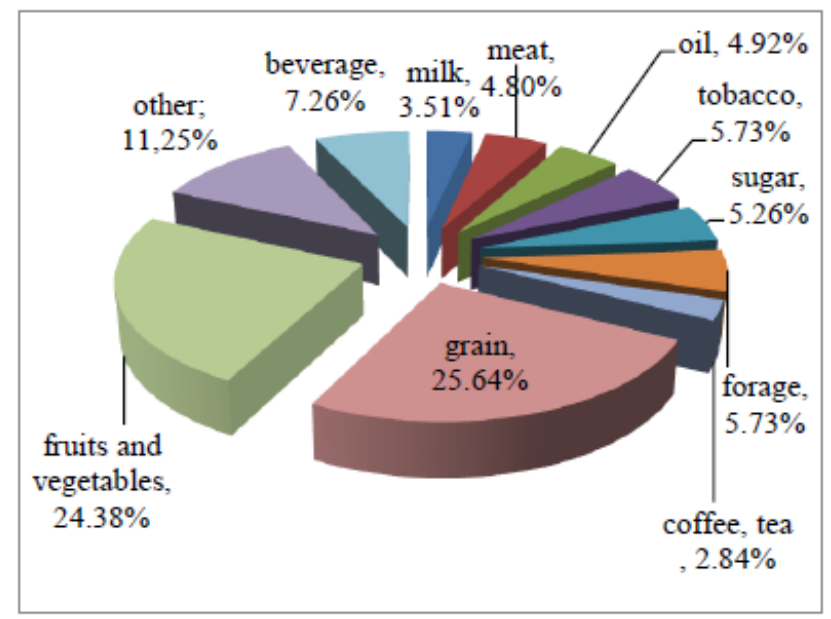

Source: Chamber of commerce and industry of Serbia 
Pie chart 2. The structure of agriculture import in 2014

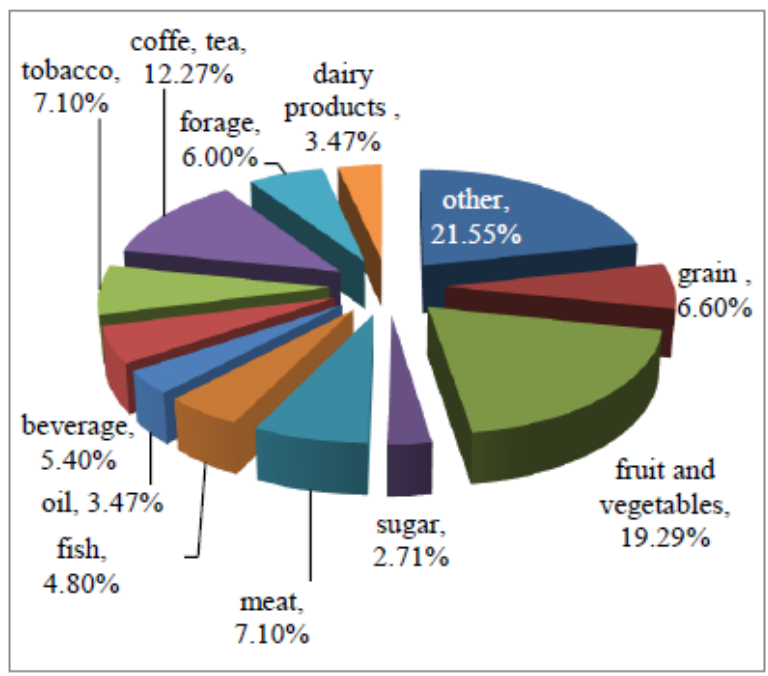

Source: Chamber of commerce and industry of Serbia

In the import structure itself (pie chart 2) we can see some products represented that are successfully produced in Serbia in large amounts. It often causes great disorders in the domestic production (pig farming, cattle farming, poultry farming, etc), and it is difficult to correct due to the nature of the agricultural activities, mainly animal husbandry. On the other hand, besides the fact that the import of these products is unjustified from the economic point of view, there is also an important question of health safety of the imported products because of the globalisation influence on the production processes in agriculture.

As for the structure of the agriculture production value in the period observed (Table 2) we can see that the share of animal husbandry is ca. $1 / 3$ (one third), except in 2012 when this share was $38.1 \%$, and the rest of the value is about crop production. Within the crop production (tillage, olericulture, pomology and viticulture) are close in relation to one another in the period observed, and the same can be said about the animal husbandry components.

Table 2. The structure of agriculture production value for the period 2010-2013 (\%)

\begin{tabular}{|l|r|r|r|r|}
\hline \multicolumn{1}{|c|}{ Description } & $\mathbf{2 0 1 0}$ & $\mathbf{2 0 1 1}$ & $\mathbf{2 0 1 2}$ & $\mathbf{2 0 1 3}$ \\
\hline Gross agriculture production & 100 & 100 & 100 & 100 \\
\hline A. Plant production & 68.91 & 68.47 & 61.9 & 67.4 \\
\hline 1. Tillage and olericulture & 59.17 & 57.1 & 50.67 & 56.12 \\
\hline 2.Pomology & 7.97 & 9.62 & 9.21 & 9.52 \\
\hline 3.Viticulture & 1.76 & 1.75 & 2.03 & 1.75 \\
\hline B. Animal husbandry & 31.09 & 31.53 & 38.1 & 32.6 \\
\hline 1. Cattle farming & 13.45 & 13.41 & 16.58 & 13.63 \\
\hline 2. Pig farming & 11.37 & 11.33 & 12.54 & 10.93 \\
\hline 3. Sheep farming & 1.82 & 1.90 & 2.66 & 2.37 \\
\hline
\end{tabular}




\begin{tabular}{|l|r|r|r|r|}
\hline Description & $\mathbf{2 0 1 0}$ & $\mathbf{2 0 1 1}$ & $\mathbf{2 0 1 2}$ & $\mathbf{2 0 1 3}$ \\
\hline 4. Poultry farming & 4.24 & 4.71 & 5.91 & 5.25 \\
\hline 5. Beekeeping & 0.21 & 0.18 & 0.40 & 0.42 \\
\hline
\end{tabular}

Source: The strategy of agriculture and rural development of the Republic of Serbia 2014-2024.

A very important link of the further economic development as a whole, agriculture included, is entrepreneurship development. Entrepreneurs are economic actors who initiate things, realise, change and terminate business ventures and processes for the sake of making a profit (Kalođera, 1990). With this objective in mind, they secure capital, organise appropriate economic mechanism to reach the objective in question, start new or expand and modernise the existing companies, organise work and management, and other things. The nucleus of the sustainable entrepreneurship contains several dimensions which show the connection and penetration of the market, quality and innovation, and their conformity with the environmental needs and limitations. There are four components of sustainable entrepreneurship-ecology, market, quality and innovation-with the equal importance and strength, with the strong mutual connection and equipment (Di Castro, 1995).

Even in agriculture in Serbia there are great possibilities for entrepreneurship and SMEs development in agribusiness. The economic policy of a state should provide a favourable macroeconomic frame for a dynamic development of entrepreneurship in agriculture. The future entrepreneurs should bear in mind that the food production is cost-effective and with a good perspective. For sustainable entrepreneur and SMEs development it is necessary to create a chain leading from the producer (the one farming the land), through the institutes and industry, to the international market, that is, cluster development around national agriculture product programmes with a lot of knowledge. This is the only way to export various products made of corn rather than the corn itself, and instead of wheat and carcasses, canned food and cereals with implemented knowledge and profitability (Devetaković et al., 2009). A good way to achieve this is to connect research and development industry sector, and to ,wrap" them into an innovative package from the idea to market realisation with the aim of competition increase of their own product.

The area of Serbia can be highly evaluated from the agricultural land availability and arable land standpoint. The agriculture production development also favours a combination of natural conditions such as climate factors, altitude, relief, etc. There are great possibilities for biologically healthy food production and export because land quality is above the European average, water and land pollution level lower than in the European Union.

An active policy of price parities establishing, incentive mechanisms of tax, credit and other policies with the simultaneous social status, work and life conditions change for farmers, that is, its balance with non-agricultural and urban population is necessary for the further successful agriculture development. The strategy of agricultural development must be a part of the unique strategy of complete economy and society development. It is the only way to establish a basis for conducting a long-term economic policy, harmonised with other development policies, and create a foundation for their proportionate action. 


\section{The results of company business in agriculture sector in Serbia}

Business companies registered for conducting the activities in the field of economy are classified according to the Decree on the Classification of the economic activities (Official Gazette number 54/2010) to sector A-agriculture, forestry and fishing. This sector, besides manufacturing industry sector, mining, electricity and water supply, belong to the tradable sectors of the economy. The companies in this sector mainly shared the destiny of the rest of the economy in Serbia in the transition period. Insufficient BDP growth and stagnation, unfavourable macroeconomic environment, high unemployment rate, etc, also caused the results in this sector.

Table 3. Property and capital movement in sector A in 2010-2013 periods (millions of dinars)

\begin{tabular}{|l|l|l|l|l|}
\hline Description & $\mathbf{2 0 1 0}$ & $\mathbf{2 0 1 1}$ & $\mathbf{2 0 1 2}$ & $\mathbf{2 0 1 3}$ \\
\hline Fixed assets & 275,749 & 285,883 & 321,523 & 347,173 \\
\hline Assets & 461,470 & 471,951 & 533,290 & 561,733 \\
\hline Current assets & 185,721 & 186,068 & 211,767 & 214,560 \\
\hline Equity & 225,636 & 235,823 & 270,623 & 303,533 \\
\hline
\end{tabular}

Source: Business Registers Agency, Statement on business economy in the Republic of Serbia in 2010, 2011, 2012 and 2013.

According to the data in Table 3, we can see that in the whole period observed the company capital is lower than the fixed assets, meaning that the fixed assets as the riskiest share in the assets is not covered by its own funds. Fixed asset capital coverage ratio ranges from $0.81 \%$ in 2010 to $0.87 \%$ in 2013 . At the same time, the share of the current assets in the total assets was $40.24 \%$ in 2010 , falling to $38.19 \%$ in 2013 .

Also, the companies were over-indebted which can be seen on the basis of the data in Table 4 , because the liabilities are larger that the capital. The ratio of debt by years was $1.16 \%$ (2010), 1.17\% (2011), 1.14\% (2012), and the situation got better in 2013 so the capital covered the liabilities. The maturity structure of liabilities was very unfavourable because there was an extremely large share of the short-term liabilities in the total liabilities of the companies, and it ranged between $76.9 \%$ in 2012 and $81.0 \%$ in 2010 and 2011. This type of liabilities structure has a negative influence on solvency, which is one of the major problems of the complete economy in the transition period. Also, these indicators show that there is no long-term source of financing in the economy, which is especially important in this sector because of its specific points.

Table 4. The structure of the financing sources in sector A business companies in 20102013 period (millions of dinars)

\begin{tabular}{|l|l|l|l|l|l|l|l|l|}
\hline Desription & $\mathbf{2 0 1 0}$ & $\mathbf{\%}$ & $\mathbf{2 0 1 1}$ & $\mathbf{\%}$ & $\mathbf{2 0 1 2}$ & $\mathbf{\%}$ & $\mathbf{2 0 1 3}$ & \% \\
\hline I Capital & 225,636 & 46.21 & 235,823 & 46.16 & 270,623 & 46.69 & 303,533 & 50.13 \\
\hline II Liabilities & 262,639 & 53.79 & 274,999 & 53.84 & 308,936 & 53.31 & 301,957 & 49.87 \\
\hline Long-term & 48,014 & 9.83 & 49,750 & 9.74 & 66,444 & 11.46 & 59,964 & 9.90 \\
\hline
\end{tabular}




\begin{tabular}{|l|l|l|l|l|l|l|l|l|}
\hline Short-term & 212,956 & 43.61 & 223,155 & 43.68 & 237,029 & 40.90 & 236,255 & 39.02 \\
\hline $\begin{array}{l}\text { Delayed tax } \\
\text { duties }\end{array}$ & 1,668 & 0.35 & 2,094 & 0.41 & 5,463 & 0.94 & 5,738 & 0.95 \\
\hline III Total & 488,275 & 100 & 510,822 & 100 & 579,559 & 100 & 605,490 & 100 \\
\hline
\end{tabular}

Source: Business Registers Agency, Statement on business economy in the Republic of Serbia in 2010, 2011, 2012 and 2013.

The solvency of the companies was at an unsatisfactory level in the complete period observed, because the general ratio values were under 1 . It implies that the short-term liabilities were larger than the total of their current assets, supplies included. The causes of company insolvency are both of internal and external character. Among the internal ones there are: management not up to the complex economic environment demands, technology level lag, late international quality standards adoption and application, high fixed and total costs, etc. The external factors to be emphasized are unfavourable economic environment, large retail chains monopoly, government debts and tax system, as well as bank sector oligopolistic position.

There was an overflow of real sector capital into the bank sector through high interest rates and other fees that banks charge for loans to businesses. Economic policy creators and the National Bank of Serbia, although they have the necessary instruments and authorities at their disposal, have not changed such an unfavourable situation for real sector companies, even though banks from the EU do business in Serbia (Italy, Austria, Greece, France) and their interest rates are much lower. The result of these relations is also the rate of return realised on the appropriations (Table 5), ranging up to $2.6 \%$ and thus being considerably lower than the interest rates exceeding $10 \%$ in certain economic loans. This is the way to reduce economy competition in the international market in the long-term. The creation of the national development bank to be professionally and non-politically led and finance long-term projects important for complete economic development, would improve the situation considerably, especially in the sector of agriculture.

Table 5. The rate of return and general ratio of solvency movement in 2010-2013 period

\begin{tabular}{|l|l|l|l|}
\hline Year & Description & $\begin{array}{l}\text { Rate of return on } \\
\text { appropriations }\end{array}$ & $\begin{array}{l}\text { General ratio } \\
\text { of solvency }\end{array}$ \\
\hline \multirow{2}{*}{$\mathbf{2 0 1 0}$} & Business companies-total & 0.2 & 0.95 \\
& Sector A: agriculture, forestry and fishing & -1.9 & 0.87 \\
\hline \multirow{2}{*}{$\mathbf{2 0 1 1}$} & Business companies-total & 2.1 & 0.93 \\
& Sector A: agriculture, forestry and fishing & -1.0 & 0.84 \\
\hline \multirow{2}{*}{2012} & Business companies-total & 0.4 & 0.95 \\
& Sector A: agriculture, forestry and fishing & 2.1 & 0.89 \\
\hline \multirow{2}{*}{013} & Business companies-total & 0.9 & 0.89 \\
& Sector A: agriculture, forestry and fishing & 2.6 & 0.90 \\
\hline
\end{tabular}

Source: Business Registers agency, Statement on business economy in the Republic of Serbia in 2010, 2011, 2012 and 2013. 
The data in the text above point to the necessity for the new agricultural policy creation, based on the modern management model and the developed European countries' experiences. These assumptions precisely define the need to specify the integral rural development policy and the necessity to innovate the existing models of organisation.

It is expected that the state should define the frame for political and institutional change. This will result in more efficient agriculture development. This policy should secure a sustainable agriculture development, environment protection and sustainable natural resources management. The results of such a policy would be production volume increase as well as a long-term competition increase in the international market.

\section{Conclusion}

There are undisputed claims for food production increase, rational and organized distribution of agricultural and food products to all parts of the world. Disregarding the economic theory which explains that a larger share of agricultural and food products exports in the total exports of a country as a rule points to its lower level of economic development, there are many developed countries in the world where the export of these products make an important item in the foreign trade balance (Holland, Denmark, France, Canada, Australia). Agriculture can bring economic development, increase GDP and become the framework of total economic stability. Agriculture should not be a symbol of poverty, but the wealth of a country, because through it natural, human and manufacturing capacities of an economy can be valorized up to the maximum.

Agricultural development in Serbia is the result of the condition inherited from the post-war period and the agricultural policy conducted during that period. Agricultural development was mainly based on the public sector, through cooperatives and large agricultural conglomerates. Agriculture was neglected compared to industry and other economic areas in the complete post-war period, especially through price disparities at the expense of agriculture, and that is still kept nowadays. A slower agriculture growth is the result of the inconsistencies in the formulation and implementation of the development concept, as well as the neglect of the private sector in the economic policy. Regardless of that situation, we should point out the importance of agriculture in the foreign trade balance and the total employment, with regard to the problems of the debts of the country and a high rate of unemployment. Further agricultural development should be based upon the higher stage of processing products exports, entrepreneurship and SMEs development incentives in agribusiness.

\section{Literature}

1. Agencija za privredne registre, Saopštenje o poslovanju privrede u Republici Srbiji u 2010, 2011, 2012 i 2013 godini (Business registers Agency, Statement on business economy in the Republic of Serbia in 2010, 2011, 2012 and 2013.).

2. Anufrijev, A., Dašić, G. (2012): Komparativne prednosti poljoprivrede Srbije i održivi razvoj, Socioeconomica, Vol. 1, No. 2, pp. 143-154. 
3. Arzeni, A., Esposti, R. Sotte, F. (2106): Agriculture in the transition countries and the European model utenti.dea.univpm.it/.../AGRICULTURE\%20U, accessed: 12th January 2016.

4. Bogavac-Cvetković, N., Ilić, B., Milićević, V. (2010): Globalizacija i konkurentnost agrarnog sektora Srbije, Ekonomske teme, Vol. 48, No. 1, pp. 159-167.

5. Byerlee, D., Janvry, A., de Sadoulet, E. (2009): Agriculture for Development: Toward a New Paradigm, Annual Review of Resource Economics, Vol. 1, pp.15-31.

6. Devetaković, S., Gavrilović-Jovanović, B., Rikalović, G. (2009): Nacionalna ekonomija, Ekonomski fakultet, Beograd.

7. Di Castro, F. (1995): The Chair of Sustainable Development, nature resources - The UNESCO journal on the environment and natural resources research, Vol. 31, No. 3 .

8. Gulan, B. (2016): DRŽAVA I SELO 1 Spasavanje sela i poljoprivredewww. makroekonomija.org posted: $9^{\text {th }}$ January, 2016.

9. Cervantes-Godoy, D. and Dewbre, J. (2010): "Economic Importance of Agriculture for Poverty Reduction", OECD Food, Agriculture and Fisheries Working Papers, No. 23, OECD Publishing.doi: 10.1787/5kmmv9s20944-en

10. European Commission (2012): Agriculture and Rural Development, available at: http:// ec.europa.eu/agriculture/index en.htm

11. Kalođera, D. (1990): Vlasništvo, struktura, poduzeće i poduzetništvo, Globus, Zagreb.

12. Milićević, D. (2012): POLJOPRIVREDA - GDE SMO STVARNO A GDE MOŽEMO $\ldots w w w . m a k r o e k o n o m i j a . o r g$, posted: $5^{\text {th }}$ June, 2012.

13. Pejanović, R., Milanović, M., Cvijanović, D. (2006): Transition of Agriculture in the Republic of Serbia - achievements, effects and limitations - dometi, efekti i ograničenja, Ekonomika poljoprivrede, Vol. 53, No. 4, pp. 937-946.

14. Privredna komora Srbije (2014): (Chamber of commerce and industry of Serbia) Poljoprivreda/statistika accessible atwww.pks.rs/PrivredaSrbije.aspx? IDMeni=1057

15. Službeni glasnik RS, (2010): br. 54/2010. (Official Gazette of the Republic of Serbia, number 54/2010.)

16. Statistički godišnjak, (2015): Republički zavod za statistiku, (Statistical Yearbook, (2015). Statistical Office of the Republic of Serbia.)

17. Stefanović, R., Broćić, Z. (2012): Kvalitet kao determinanta rasta izvoza poljoprivrednoprehrambenih proizvoda Republike Srbije; FQ2012-Festival kvaliteta, pp. A267-A273.

18. Strategija poljoprivrede i ruralnog razvoja Republike Srbije 2014-2024. godine, "Sl. glasnik RS", br. 85/2014. (The strategy of agriculture and rural development of the Republic of Serbia 2014-2024.)

19. Vapa-Tankosić, J., Stojsavljević, M. (2014): EU Common Agricultural Policy and Preaccession Assistance Measures for Rural Development, Ekonomika poljoprivrede, Vol. 61, No. 1, pp. 195-210.

20. Zakić, N., Vukotić, S., Cvijanović, D. (2014): Organisational Models in Agriculture 
with Special Reference to Small Farmers, Ekonomika poljoprivrede, Vol. 61, No. 1, pp. 225-239.

\title{
STRATEŠKI ASPEKTI I REZULTATI RAZVOJA POLJOPRIVREDE SRBIJE U TRANZICIONOM PERIODU
}

\author{
Jugoslav Aničićc ${ }^{4}$ Svetlana Vukotić5 ${ }^{5}$ Svetozar Krstićc
}

\begin{abstract}
Sažetak
Privredni razvoj Jugoslavije (Srbije) posle drugog svetskog rata se odvijao na štetu poljoprivrede, jer je industrijalizacija bila u prvom planu ekonomske politike. To se reflektovalo na sadašnju poziciju sektora agrara u odnosu na ostale sektore jer su $i$ dalje zadržani pariteti razmene proizvoda na štetu poljoprivrede. I u takvim uslovima, poljoprivreda je delatnost koja ima pozitivan spoljnotrgovinski bilans, značajno učešće u društvenom proizvodu i u smanjenju stope nezaposlenosti, što je analizirano i pokazano u radu. Mnoge razvijene zemlje u Evropi su primer da uspešan razvoj agrara može da bude nosilac celokupnog razvoja. U Srbiji su nesporne znatno veće mogućnosti razvoja agrara koji, uz adekvatnu makroekonomsku politiku, može da postane velika komparativna prednost naše privrede na razvijenim svetskim tržištima.
\end{abstract}

Ključne reči: poljoprivreda, razvoj, ekonomska politika, rezultati poslovanja, preduzeće

4 Vanredni profesor, dr Jugoslav Aničić, Univerzitet Union - Nikola Tesla, Ulica Cara Dušana br. 62-64, Beograd, Republika Srbija, Telefon: +381 1132869 61, E-mail: ajugoslav@yahoo.com

5 Vanredni profesor, dr Svetlana Vukotić, Univerzitet Union - Nikola Tesla, Ulica Cara Dušana br. 62-64, Beograd, Republika Srbija, Telefon: +381 1134281 42, E-mail: cecavukotic@gmail.com

6 Magistar Svetozar Krstić, Privredna Komora Beograda, Ulica Kneza Miloša br. 12, 11000 Beograd, Republika Srbija, E-mail: krstics@,kombeg.org.rs

EP 2016 (63) 1 (175-187) 